\title{
Geosmithia Species in Florida: Common Fungal Symbionts of Wood-Boring Bark Beetles ${ }^{1}$
}

\author{
Yin-Tse Huang and Jiri Hulcr ${ }^{2}$
}

\section{Summary}

Geosmithia is a genus of ubiquitous fungal symbionts of wood-boring bark beetles. Most Geosmithia species are saprophytic and do not harm the host trees when the beetles enter the bark. One exception is the canker-causing Geosmithia morbida. This fungus, together with its beetle vector, the walnut twig beetle (WTB), are key elements of the disease complex known as thousand cankers disease (TCD) on walnut trees. TCD is widespread throughout the western United States and has a scattered distribution in the eastern United States. Continuous surveys in Florida have found neither Geosmithia morbida nor its beetle vector present in the state. Instead, many native Geosmithia species have been recovered in this region on walnut trees and their relatives. These native Geosmithia species also live in association with bark beetles and look superficially similar to the pathogenic fungus, but these native species are harmless to their plant hosts. Here we provide basic guidelines to sample Geosmithia species in the field and information for distinguishing the plant-pathogenic Geosmithia morbida from the other, saprophytic Geosmithia species.

\section{Introduction}

Bark beetles are a group of specialized weevils that live underneath the bark of trees. They are well-known for their association with varied fungal symbionts that play diverse roles in the symbiotic relationship (Hulcr and
Stelinski 2017). Geosmithia includes numerous species that are among the most common associates with bark beetles. These fungi colonize the beetle tunnels (galleries), giving them a fluffy look (Figure 1). Most Geosmithia species are not involved in a mutualistic relationship with the beetle, but simply ride on the beetle exoskeleton to be transmitted to new tree hosts. (Kolařík and Kirkendall 2010; Kolařík et al. 2017). Geosmithia species can be found wherever bark beetles exist, both in temperate and tropical regions (Kolař́k et al. 2017).

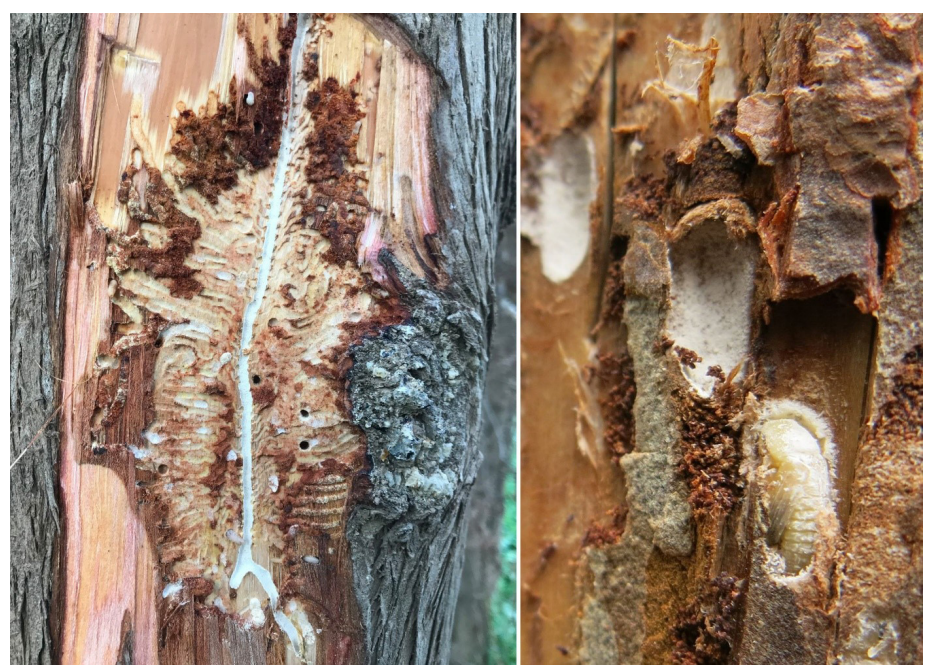

Figure 1. Galleries of Phloeosinus armatus (left) and Tomicus yunnanensis (right) colonized by Geosmithia spp.

Credits: Yin-Tse Huang and Jiri Hulcr

1. This document is FR343, one of a series of the School of Forest Resources and Conservation, UF/IFAS Extension. Original publication date January 2019. Visit the EDIS website at https://edis.ifas.ufl.edu for the currently supported version of this publication.

2. Yin-Tse Huang, PhD student, School of Forest Resources and Conservation; and Jiri Hulcr, associate professor, School of Forest Resources and Conservation and Department of Entomology and Nematology; UF/IFAS Extension, Gainesville, FL 32611. 
Most Geosmithia species are generally saprophytic and cause no harm to the tree host. The main reason Geosmithia has recently received attention is because of the exceptional case of the species Geosmithia morbida, which is a cankercausing fungus and is vectored primarily by the walnut twig beetle (WTB, Pityophthorus juglandis). The beetle and the fungus together synergistically cause the disease known as thousand cankers disease (TCD) on walnut trees (Juglans spp.) and their relatives (Kolařík et al. 2011).

\section{Thousand Cankers Disease (TCD)}

Thousand cankers disease has generated attention since the early 2000s because of the widespread decline of walnut trees in Colorado and California (Tisserat et al. 2009). The fungus and the vector are widespread across the western United States but have a scattered distribution in the East. TCD has been confirmed in six eastern states, namely, Ohio, Pennsylvania, Maryland, Virginia, North Carolina, and Tennessee (USDA Forest Service et al. 2014). Other than North Carolina and Tennessee, no case of TCD has been recorded in any of the southeastern states, including Florida.

Walnut trees are slowly colonized by massive numbers of WTB beetles carrying the canker-causing Geosmithia morbida. Mass colonization of WTB beetles results in thousands of inoculation points introducing the cankercausing fungus, which then causes lesions. Lesions damage the tree's vascular system and may eventually kill parts of the affected tree. In severe cases, the entire tree can be killed. The affected walnut tree first shows yellowing and thinning of the canopy, especially on the crown branches (a symptom known as flagging). As the disease progresses, the larger branches and main trunk are infected and can eventually lead to the tree's death (Figure 2). Trees may die within two to three years after showing initial TCD symptoms. The outbreaks of TCD appear to be partially a result of drought stress of the trees. Drought-stressed walnuts are predisposed to WTB colonization and tend to display faster disease progress. (Tisserat et al. 2011 and 2009). Even if trees are already colonized by the beetle-fungus complex, they often improve and resume growth with improved environmental conditions.

Thousand cankers disease can affect walnut species (Juglans spp.) and some wingnut trees (Pterocarya spp.) (Hishinuma 2017; Hishinuma et al. 2016). Among these tree hosts, black walnut (Juglans nigra) is the most susceptible host to this disease complex. Black walnut is a native species to North America and has significant economic and ecological value. Unfortunately, its native range completely overlaps with the current reported distribution of TCD (USDA Forest Service et al. 2014). Active surveillance of both WTB and Geosmithia morbida is essential to prevent the spread of

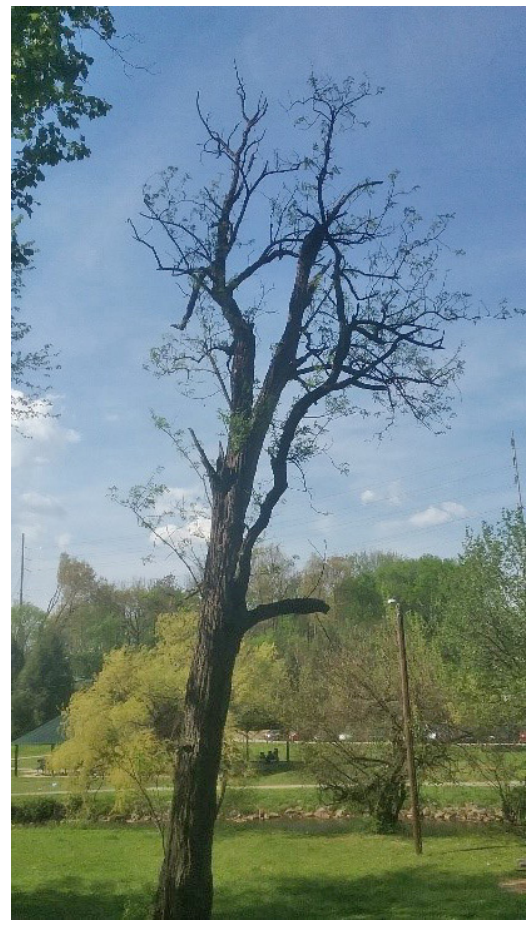

Figure 2. Late symptoms of thousand canker disease (TCD) on a black walnut tree showing thinning and yellowing leaves on the crown branches.

Credits: Romina Gazis

TCD into new areas.

\section{The Causal Agents of the Thousand Canker Disease Do Not Occur in Florida}

TCD monitoring starts with the detection of the walnut twig beetle because that is the mobile agent that specifically attacks walnut trees and spreads the canker-causing fungus. Multiple funnel traps with aggregate pheromone lure are recommended for monitoring the existence of WTB in regions where valuable walnut stands exist or where walnut trees show decline symptoms (USDA APHIS 2018). Alternatively, excised branches of walnut trees may be hung in the crown to detect the occurrence of WTB. Importantly, if a walnut tree displays an unexplained decline or even an early symptom of TCD (yellowing and thinning of small-diameter branches), it is recommended to contact the local Cooperative Extension representative or a county forester for accurate diagnosis (see Florida Forest Service: https://www.freshfromflorida.com/Divisions-Offices/ Florida-Forest-Service) 
Surveys of TCD in Florida have detected neither the WTB nor Geosmithia morbida (Huang \& Hulcr, unpublished data). Florida has scattered distribution of black walnut and tree genera that are closely related to walnuts such as pecan (Carya illinoensis) and pignut hickory (Carya glabra). Fortunately, these species are not affected by the WTB and Geosmithia morbida (Utley et al. 2012).

Many other Geosmithia species occur in Florida and are routinely found in association with bark beetles. Their ubiquity in forested ecosystems is analogous to what has been reported in the western United States (Kolařík et al. 2017) and in Europe (Jankowiak et al. 2014; Kolařík and Jankowiak 2013). Importantly, these Geosmithia species are likely to be native species, which suggests that they have interacted with local bark beetles and trees for a long time and have maintained a stable relationship with organisms in this ecosystem. Given the fact that most Geosmithia species are doing no harm to the tree host, it is essential for us to differentiate the canker-causing Geosmithia morbida from other Geosmithia species.

\section{Geosmithia Species in Florida}

Generally, Geosmithia species can be readily found in the field with a proper hand lens and with basic knowledge of the signs of the presence of bark beetles. We detect bark beetles by spotting recently dead branches with entrance/ exit holes of bark beetles that are usually less than $3 \mathrm{~mm}$ wide. Geosmithia are commonly associated with bark beetles, especially those that feed on phloem in smalldiameter branches (less than $7 \mathrm{~cm}$ ). The growth of Geosmithia in the tunnels of bark beetles gives the galleries a fluffy appearance with varied colors (Figure 1), e.g., brown, white, or violet, depending on the species of Geosmithia. Penicillium, a common fungal contaminant, often takes over the galleries right after the beetles abandon them or disperse from the galleries. However, Penicillium species usually produce a greenish color; Geosmithia do not. Interestingly, some common mold contaminants of bark beetle galleries (e.g. Penicillium and Paecilomyces) have made the study of Geosmithia historically complicated compared to the other fungal symbionts of bark beetles due to their morphological similarities. Nowadays, molecular tools combined with analysis of morphological characteristics can reliably distinguish Geosmithia from other fungal contaminants (Kolařík et al. 2004; Pitt 1979).

In Florida, we have many native Geosmithia species that should not be confused with Geosmithia morbida. Geosmithia morbida is a host-specific species that, with a few exceptions, has been recovered almost exclusively from the walnut twig beetle (Juzwik et al. 2016, 2015). Most Geosmithia morbida isolates can be distinguished by (1) flat, yellowish colonies with lobed margins (Figure 3 ) and (2) growth at $37^{\circ} \mathrm{C}\left(98.6^{\circ} \mathrm{F}\right)$. The combination of host specificity

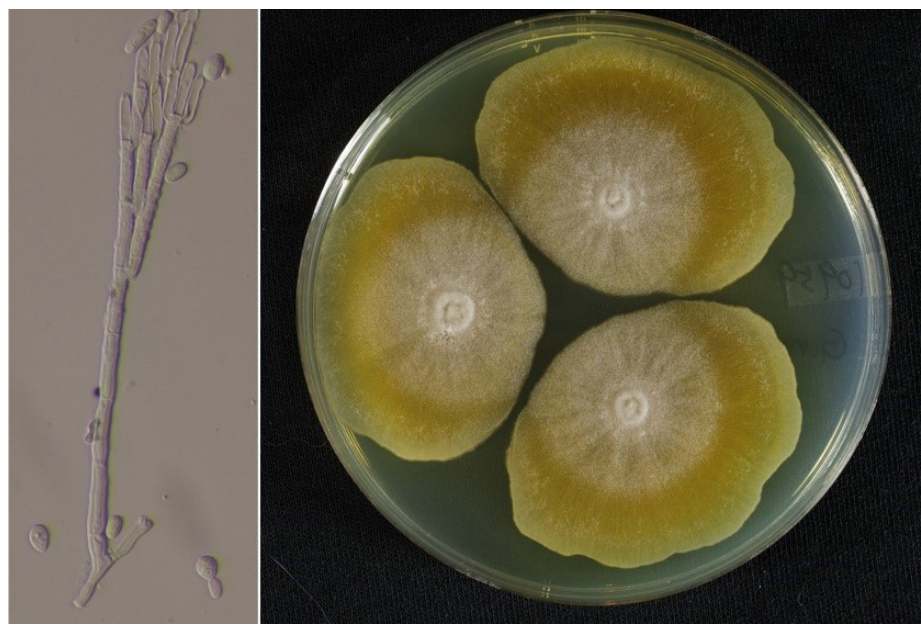

Figure 3. Fruiting body (left) and colony (right) of Geosmithia morbida. Credits: Yin-Tse Huang and Jiri Hulcr

and colony morphology makes Geosmithia morbida unique among described species of Geosmithia (Kolařík et al. 2011).

\section{References}

Hishinuma, S. 2017. Interactions among the Walnut Twig Beetle, Pityophthorus Juglandis, the pathogenic fungus, Geosmithia Morbida, and host species in thousand cankers disease in California (Ph.D. thesis). University of California, Davis, United States.

Hishinuma, S. M., P. L. Dallara, M. A. Yaghmour, M. M. Zerillo, C. M. Parker, T. V. Roubtsova, T. L. Nguyen, N. A. Tisserat, R. M. Bostock, M. L. Flint., and S. J. Seybold. 2016. "Wingnut (Juglandaceae) as a new generic host for Pityophthorus juglandis (Coleoptera: Curculionidae) and the thousand cankers disease pathogen, Geosmithia morbida (Ascomycota: Hypocreales)." Can. Entomol. 148, 83-91. doi:10.4039/tce.2015.37

Hulcr, J., and L. L. Stelinski. 2017. “The ambrosia symbiosis: From evolutionary ecology to practical management." Annu. Rev. Entomol. 62, 285-303. doi:10.1146/ annurev-ento-031616-035105

Jankowiak, R., M. Kolařík, and P. Bilański. 2014. “Association of Geosmithia fungi (Ascomycota: Hypocreales) with pine- and spruce-infesting bark beetles in Poland." Fungal Ecol. 11, 71-79. doi:10.1016/j.funeco.2014.04.002 
Juzwik, J., M. T. Banik, S. E. Reed, J. T. English, and M. D. Ginzel. 2015. "Geosmithia morbida found on weevil species Stenominus pallidus in Indiana." Plant Health Prog. 16, 7-10.

Juzwik, J., M. McDermott-Kubeczko, T. J. Stewart, and M. D. Ginzel. 2016. "First report of Geosmithia morbida on ambrosia beetles emerged from Thousand Cankersdiseased Juglans nigra in Ohio." Plant Dis. 100, 1238-1238. doi:10.1094/PDIS-10-15-1155-PDN

Kolařík, M., E. Freeland, C. Utley, and N. Tisserat. 2011. "Geosmithia morbida sp. nov., a new phytopathogenic species living in symbiosis with the walnut twig beetle (Pityophthorus juglandis) on Juglans in USA." Mycologia 103, 325-332. doi:10.3852/10-124

Kolařík, M., J. Hulcr, N. Tisserat, W. D. Beer, M. Kostovčík, Z. Kolaříková, S. J. Seybold, and D. M. Rizzo. 2017. "Geosmithia associated with bark beetles and woodborers in the western USA: taxonomic diversity and vector specificity." Mycologia 109, 185-199. doi:10.1080/00275514.2017.1303 861

Kolařík, M., and R. Jankowiak. 2013. "Vector affinity and diversity of Geosmithia fungi living on subcortical insects inhabiting pinaceae species in central and northeastern Europe." Microb. Ecol. 66, 682-700. doi:10.1007/ s00248-013-0228-x

Kolařík, M., and L. R. Kirkendall. 2010. "Evidence for a new lineage of primary ambrosia fungi in Geosmithia Pitt (Ascomycota: Hypocreales)." Fungal Biol. 114, 676-689. doi:10.1016/j.funbio.2010.06.005

Kolařík, M., A. Kubátová, S. Pažoutová, and P. Šrûtka. 2004. "Morphological and molecular characterisation of Geosmithia putterillii, G. pallida comb. nov. and G. flava sp. nov., associated with subcorticolous insects." Mycol. Res. 108, 1053-1069. doi:10.1017/S0953756204000796

Pitt, J. I. 1979. “Geosmithia gen. nov. for Penicillium lavendulum and related species." Can. J. Bot. 57, 2021-2030. doi:10.1139/b79-252

Tisserat, N., W. Cranshaw, D. Leatherman, C. Utley, and K. Alexander. 2009. "Black walnut mortality in Colorado caused by the walnut twig beetle and thousand cankers disease." Plant Health Prog. doi:10.1094/PHP-2009-0811-01-RS

Tisserat, N., W. Cranshaw, M. L. Putnam, J. Pscheidt, C. A. Leslie, M. Murray, J. Hoffman, Y. Barkley, K. Alexander, and
S. J. Seybold. 2011. "Thousand cankers disease is widespread on black walnut, Juglans nigra, in the western United States." Plant Health Progress. doi:10.1094/PHP-2011-063001-BR. Available: https://www.plantmanagementnetwork. org/pub/php/brief/2011/walnut/.

United States Department of Agriculture Animal and Plant Health Inspection Service. Thousand Cankers Disease (website). 2018. Available at: https://www.aphis.usda. gov/aphis/ourfocus/planthealth/plant-pest-and-diseaseprograms/pests-and-diseases/thousand-cankers-disease/ ct_thousand_cankers_disease. (accessed 9.15.2018).

United States Department of Agriculture Forest Service, the Purdue University Department of Forestry and Natural Resources et al. Thousand Cankers Disease (website). 2014. Available at: http://www.thousandcankers.com/ (accessed 6.25.18).

Utley, C., T. Nguyen, T. Roubtsova, M. Coggeshall, T. M. Ford, L. J. Grauke, A. D. Graves, C. A. Leslie, J. McKenna, K. Woeste, M. A. Yaghmour, S. J. Seybold, R. M. Bostock, and N. Tisserat. 2012. "Susceptibility of Walnut and Hickory Species to Geosmithia morbida." Plant Dis. 97, 601-607. doi:10.1094/PDIS-07-12-0636-RE 